\title{
Controllable Transdermal Drug Delivery of Theobroma cacao Extract Based Polymeric Hydrogel against Dermal Microbial and Oxidative Damage
}

\section{Shriya Agarwal', Vandana Tyagi ${ }^{1}$, Mugdha Agarwal', Arushi Pant ${ }^{1}$, Harleen Kaur ${ }^{2}$, Rachana ${ }^{1}$, Manisha Singh ${ }^{*}$}

${ }^{1}$ Department of Biotechnology, Jaypee Institute of Information Technology, Noida, India

${ }^{2}$ Amity Institute of Biotechnology, Amity University, Noida, India

Email: *manishasingh1295@gmail.com

How to cite this paper: Agarwal, S., Tyagi, V., Agarwal, M., Pant, A., Kaur, H., Rachana and Singh, M. (2019) Controllable Transdermal Drug Delivery of Theobroma cacao Extract Based Polymeric Hydrogel against Dermal Microbial and Oxidative Damage. Food and Nutrition Sciences, 10, 1212-1235.

https://doi.org/10.4236/fns.2019.1010088

Received: September 11, 2019

Accepted: October 26, 2019

Published: October 29, 2019

Copyright $\odot 2019$ by author(s) and Scientific Research Publishing Inc. This work is licensed under the Creative Commons Attribution International License (CC BY 4.0).

http://creativecommons.org/licenses/by/4.0/

\begin{abstract}
Human dermal layers are directly bared to the external environmental adversities like pollution, radiation, dust along with various chemical and mechanical stress conditions which constantly lead to the oxidative stress, eventually forming free radicals. These conditions also support the dermal microbial infections by invading the cutaneous layers. Therefore, the most efficient approach accepted globally to combat these complications is to opt for transdermal application of exogenous antioxidants which helps in reducing the ill effects of oxidative stress and promotes the DNA repair. However, many scientific findings exhibited the potential role of Theobroma cacao for providing efficient skin protection. Theobroma cacao known for its vital procyanidin flavonoids, phenolic compounds, methylxanthines, catechin and epicatechin phytoconstituents with numerous health benefits, besides helping in smoothening and softening the damaged skin. These therapeutic benefits of cocoa phytocompounds are attributed to its anti-inflammatory and antioxidative characteristics. This study addresses the fabrication and optimizations of Theobroma cacao extract loaded carbopol hydrogel system for increased antioxidative and antimicrobial effects. It was found in the studies that the hydrogel-based T. cacao extract (TCHG) has significantly improved the therapeutic index of the extract, making it more suitable for transdermal application. The optimized hydrogel was further characterized by physicochemical parameters, SEM analysis and in-vitro release kinetics. The reported findings showed the sustained compound release with comparatively significant antimicrobial activity of TCHG against microbial (Pseudomonas
\end{abstract}


fluorescens, Bacillus licheniformis, Micrococcus luteus, Aspergillus niger, Trichoderma harzianum, Rhizopus oryzae) infections. Also, the higher ROS quenching ability of TCHG as compared to T. cacao extract promises to be an effective transdermal formulation.

\section{Keywords}

Theobromine, Hydrogel, Oxidative Stress, Release Kinetics, Transdermal

\section{Introduction}

Human skin is the most contacted and directly exposed organ known and thus, has multi-layered defense barrier systems for protection from external stress causes [1] [2] [3]. The dermal endogenous mechanism secures the cellular continuity, immunological balances, enzymatic defenses and cutaneous homeostasis, however, the exogenous compounds like ascorbic acid (AA), vitamin E, lycopene, cocoa etc. counter the quenching of ROS (Reactive Oxygen Species) besides, enhancing the antimicrobial properties [4] [5]. The flavonol and phenolic content of cocoa are also reported to contribute to enhancing the endogenous mechanism [6]. Cocoa also known as Theobroma cacao (T. cacao), sub-classified as Criollo, Forestero or Trinitario varieties has an essential phytoconstituents, theobromine (3,7-dihydro-3,7-dimethyl-1H-purine-2,6-dione) which belongs to the category of methylxanthines and affiliates to alkaloids (purine), affecting many physiological processes in body [7] [8] [9]. The pharmacological and toxicological properties of theobromine and other methylxanthines have been reviewed by many researchers and the chemical profile of roasted cocoa beans was found to be more complex [10]. But the primary compounds that induce its multiple beneficial functions are either naturally occurring or process-derived flavonoids, theobromine and magnesium [11]. It's been widely reported that the theobromine, an essential phytocompounds of $T$. cacao, scavenges reactive oxygen species (ROS) generated within the skin as a consequence of UV exposure, hormonal dysfunctioning, aging and other environmental factors which interfere with altered signaling pathways in the skin as a consequence [12] [13] [14]. Moreover, Cocoa's polyphenolic phytocompounds also help in delaying and reducing, the age-related brain impairments, including cognitive deficits in normal aging and perhaps neurodegenerative diseases too. It's also been reported to provide protection against nerve injuries, inflammation and persuade coronary vasodilatations and intensify endothelial nitric oxide content to prompt vascular slackening, expand vascular utility and also decline platelet linkage [15] [16] [17]. In the same way, polyphenols have anti-inflammatory action, over the inhibition of dissimilar transcription elements and cytokines [18] [19]. However, the current developments in pharmacological data has enhanced the competence of fragments to permit over the skin by refining the pharmacokinetics of medications; but then there is no sufficient and appropriate vehicle, that stayed de- 
veloped, to safeguard intense, stable and uninterrupted sustained drug delivery using non-invasive and patient compliant techniques [20] [21] [22]. Most of the dermal formulations developed are either cream or lotion based which doesn't permeate well through the skin and are less absorptive, therefore, other pharmaceutical intervention which can enhance the absorption and permeation through the multi-layered dermal structure is always preferred [22].

Hydrogels are unique materials that are elastic in nature and have a broad range of applications in cosmetics, medicine, biomaterials and food technologies [23]. They allow higher degree of dermal hydration, drug transportation and dissolution, proving to be a suitable candidate for transdermal application. Many therapeutic agents such as curcumin, turmeric, neem and sandalwood have been loaded in hydrogels for the purpose of efficient skin damage healing and treating infections [24]. It was suggested that the combination of bioactivity of cocoa encapsulated in hydrogel system may prove beneficial in treating skin infections, reducing skin oxidative stress and has a potential for cutaneous healing ability. Therefore, in the present study, we opted for developing $T$. cacao extract loaded hydrogel formulation that will be more patient compliant, would have higher impregnation and absorbability for transdermal application [24] [25] [26].

\section{Materials and Methodology}

\section{Materials}

Theobroma cacao purified extract was provided by AESTHETIC company, Saharanpur, Uttar Pradesh, India as a gift sample and Folin-Ciocalteu reagent, gallic acid, Carbopol-940 and glycerin, 2,2-diphenyl-1-picrylhydrazyl (DPPH), azino-bis(3-ethylbenzothiazoline-6-sulfonic acid) (ABTS), $\mathrm{H}_{2} \mathrm{O}_{2}$ reagent, Griess reagent, sodium nitroprusside were procured from Sigma Aldrich (USA). All other chemicals used in the experiments were of analytical grade.

\section{Methodology}

\subsection{Sample Preparation (T. cacao Extract)}

The T. cacao extract was prepared by defatting the cocoa butter from the extract completely with no loss of polyphenolic content as reported by P. Camasca, meeting the current regulation and ordinance standards regarding cocoa processing [27]. Then the cocoa extract ( 2 grams) was mixed with $10 \mathrm{ml}$ of $\mathrm{n}$-hexane solution and kept in a tightly capped reagent bottle on shaker for 24 hours. Thereafter, the defatted extract solution was subjected for ultra-sonication $(25 \mathrm{kHz})$ for 30 minutes followed by a filtration and drying of filtrate in a vacuum-dryer (DZF-6050) at $37^{\circ} \mathrm{C}$ and stored at $-20^{\circ} \mathrm{C}$ for further use [28] [29] [30].

\subsection{Total Phenolic Estimation}

Phenols react with phosphomolybdic acid in Folin-Ciocalteu chemical in an al- 
kaline medium to impart a blue-colored complex (molybdenum blue) which is then estimated and calculated spectrophotometrically at $765 \mathrm{~nm}$ [31]. The amount of total phenolic in $T$. cacao extracts (TCE) was determined by adding 1 $\mathrm{ml}$ of Folin-Ciocalteu reagent in $2 \mathrm{ml}$ TCE followed by the addition of $0.5 \mathrm{ml}$ of $\mathrm{Na}_{2} \mathrm{CO}_{3}$ solution. The reaction mixture was then incubated for 30 minutes; thereafter the absorbance was recorded at $765 \mathrm{~nm}$. The gallic acid was taken as a standard and the values after calculation were expressed as gallic acid equivalents (GAE) [32].

\subsection{Total Flavonoid Estimation}

For quantifying the total flavonoid content in the given TCE sample, they were subjected for the aluminium chloride $\left(\mathrm{AlCl}_{3}\right)$ colorimetric method as reported by Lamuela-Raventós, A. Tornero et al. In this assay, there is a development of acid constant multiplexes with C-4, C-3, and C-5 keto groups of flavones when mixed with $\mathrm{AlCl}_{3}$ and subsequently, leads to formation of aluminium chloride rings which are acid stable complex with ortho-dihydroxyl groups [33]. Gallic acid was used as a standard and different concentrations TCE $(10-50 \mu \mathrm{g} / \mathrm{ml})$ was prepared in methanol and to this $0.2 \mathrm{ml}$ aluminium chloride, $0.1 \mathrm{ml}$ potassium acetate solution and $2.5 \mathrm{ml}$ distilled water (DW) was added. After the 30 minutes of incubation, the absorbance of the samples was measured at $415 \mathrm{~nm}$ [34] [35].

\subsection{Preparation of T. cacao Extract Loaded Hydrogel (TCHG)}

The hydrogels are prepared and molded through various biochemical or physical crosslinks that construct the system and physical steadiness. These physical cross linkages include van der Waals interfaces or hydrogen attachment. Here in the present study, we have prepared the T. cacao defatted extract solution (TCE) loaded polymeric hydrogel by dispersion method [36] [37]. To prepare the gel carbopol-940 $(10 \mu \mathrm{g} / \mathrm{ml})$ was dispersed in water for two hours to get swollen up gelling mixture under constant mild stirring [38]. Further, the prescribed amount of TCE $(10 \mu \mathrm{g} / \mathrm{ml})$ was added in the gelling mixture along with triethanolamine $(5 \mu \mathrm{g} / \mathrm{ml})$ and glycerin $(30 \mu \mathrm{g} / \mathrm{ml})$ to maintain the $\mathrm{pH}$ and improve viscosity of the prepared hydrogel (TCHG). The optimization of the prepared formulation was done on the basis of various physicochemical as well as release kinetics parameters [38] [39].

\section{Characterization of TCHG}

\subsection{Measurement of Physicochemical Parameters of TCHG ( $\mathrm{pH}$, Viscosity and Appearance)}

The $\mathrm{pH}$ of all prepared TCHG formulations was measured by preparing $1 \%$ aqueous solution of the same and measuring it by using a calibrated digital $\mathrm{pH}$ meter (Mettler Toledo MP 220, Greifensee, Switzerland) at $37^{\circ} \mathrm{C}$. Subsequently, these formulations were also analyzed for viscosity which was determined by viscometer (Brookfield viscometer) at various angular velocities and then TCHG 
formulations were inspected visually for the colour, odor and consistency [40] [41] [42].

\subsection{Determination of Spreadability}

The spreadability analysis of optimized hydrogel formulation (TCHG) was done by determining range of the expanded diameter of TCHG, when $500 \mathrm{mg}$ of the same was placed between the two glass plates. The glass plates were left for 1 minute so that the gel can spread over maximally within a circle. Thereafter, the attained diameter of the spread gel on glass plates was measured. The shorter the time interval, the better will be the spreading coefficients [42].

\subsection{Scanning Electron Microscopy Analysis (SEM)}

The surface morphology and shape of the optimized TCHG was analyzed by SEM (Scanning electron microscopy). The sample for the same was prepared by mounting the hydrogel with adhesive tape which was conductive in nature on the aluminium surface followed by coating the surface with gold sputtering under vacuum condition and the surface morphology was observed on SEM (ZEISS, EVO 18, Germany) at $15 \mathrm{KV}$ voltage [43] [44].

\section{Antioxidant Analysis}

\subsection{DPPH (2,2-Diphenyl-1-Picrylhydrazyl) Assay}

DPPH is widely used antioxidant assay for analyzing the scavenging ability of a compound against free radicals [45]. The antioxidative effect in this assay is measured on the basis of fading away of DPPH (free radical) in test samples which turns purple to yellow color as soon as the DPPH formed by absorption of hydrogen from the antioxidant reduces. Similarly, here in the experiment, $0.5 \mathrm{ml}$ of DPPH solution was added in $500 \mu \mathrm{l}$ of the test samples (AA, TCE and TCHG) prepared in different concentrations $(10-50 \mu \mathrm{l})$ and incubated for 30 minutes at $37^{\circ} \mathrm{C}$ followed by recording the $\lambda$ maxima at $517 \mathrm{~nm}$ [46] [47] [48].

The scavenging ability (\%) of each test samples were calculated by below mentioned formula:

$$
\text { Scavenging activity }(\%)=\frac{A_{(\mathrm{OC})}-A_{(\mathrm{OS})}}{A_{(\mathrm{OC})}} \times 100
$$

where, $A_{(\mathrm{OC})}$ and $A_{(\mathrm{OS})}$ refer to the absorbance of the control and sample at 517 $\mathrm{nm}$

\subsection{ABTS (2,2-Azinobis (3-Ethylbenzothiazoline-6-Sulfonic Acid)) Assay}

The antioxidative ability of the test samples was also estimated by ABTS assay, where ABTS is generated by persulphate oxidation of 2,2-azinobis (3-ethylbenzoline-6-sulphonic acid) radical (ABTS2•), which has a characteristic long wavelength absorption spectrum, measured at $745 \mathrm{~nm}$ [49]. The activity was es- 
timated when ABTS radical cations $\left(\mathrm{ABTS}^{+}\right)$were produced by reacting $\mathrm{ABTS}$ with $10 \mathrm{ml}$ of $2.45 \mathrm{mmol} \cdot \mathrm{L}^{-1}$ of potassium persulphate and allowing the mixture to stand for $12-16$ hours in dark at $37^{\circ} \mathrm{C}$ before use. Then in $500 \mu$ of the test samples (AA, TCE and TCHG) at different concentrations (10 - $50 \mu \mathrm{l}), 4 \mathrm{ml}$ of diluted ABTS solution was added and after 30 minutes, absorbance readings were taken at $745 \mathrm{~nm}$ [50].

The calculation for scavenging ability (\%) of each test samples is mentioned below:

$$
\text { Scavenging activity }(\%)=\frac{A_{(\text {control })}-A_{(\text {test sample) }}}{A_{(\text {control })}} \times 100
$$

where $A_{\text {(control) }}$ and $A_{\text {(test sample) }}$ refers to the absorbance of the control and sample at $745 \mathrm{~nm}$.

\subsection{Hydrogen Peroxide Scavenging Ability $\left(\mathrm{H}_{2} \mathrm{O}_{2}\right.$ Assay)}

Hydrogen peroxides $\left(\mathrm{H}_{2} \mathrm{O}_{2}\right)$ are the free radical reactive oxygen species (ROS) which are produced as the by-products of normal aerobic metabolism and increases during a stressed condition, infections, exercise, radiation etc. $\mathrm{H}_{2} \mathrm{O}_{2}$ is not toxic itself but eventually, under the mentioned conditions may get converted into even more toxic radicals (hydroxyl radicals) and thus, its removal is important [51]. $\mathrm{H}_{2} \mathrm{O}_{2}$ scavenging activity is based on the direct UV-Vis absorption measurement at $230 \mathrm{~nm}\left(\mathrm{~A}_{230}\right)$. For assay, in the different concentration of test samples (AA, TCE and TCHG) ranging from $10-50 \mu \mathrm{g} / \mathrm{ml}, 500 \mu \mathrm{l}$ of $\mathrm{H}_{2} \mathrm{O}_{2}$ was added in of the test samples and incubated for 10 minutes at room temperature [52] [53] [54] [55].

The absorbance was measured at $230 \mathrm{~nm}$ and calculated as:

$$
\text { Scavenging activity }(\%)=\frac{\text { control absorbance }- \text { sample absorbance }}{\text { control absorbance }} \times 100
$$

where absorbance of the control and sample is at $230 \mathrm{~nm}$.

\subsection{Nitric Oxide (NO) Scavenging Activity}

NO assay was originally described by Griess in 1879 and involves the chemical reaction between sulfanilamide and naphthyl ethylenediamine dihydrochloride (NED) under acidic conditions [56]. Nitric oxide scavenging activity is based on the diazotization reactions which lead to the formation of chromophoricazo-derivative of sulphanilamide and naphthyl ethylenediamine dihydrochloride (NED). The NO scavenging activity was estimated by taking $0.25 \mathrm{ml}$ of $10 \mathrm{mM}$ sodium nitroprusside dissolved in phosphate buffer solution ( $\mathrm{pH}$ 7.2). Different concentrations of the test samples $(10-50 \mu \mathrm{l} / \mathrm{ml})$ were incubated for 3 hours at $37^{\circ} \mathrm{C}$ with $500 \mu \mathrm{l}$ of Griess reagent [57] [58].

The absorbance was measured at $546 \mathrm{~nm}$ and calculated as following:

$$
\text { Scavenging activity }(\%)=\frac{I_{O}-I_{1}}{I_{O}} \times 100
$$


where $I_{\mathrm{O}}$ and $I_{1}$ refer to the absorbance of the blank and sample respectively at $546 \mathrm{~nm}$.

\subsection{Antimicrobial Activity by Agar Well-Diffusion Assay}

The TCE and TCHG were screened for their antimicrobial potential using agar well diffusion assay. The microbial cultures Micrococcus Luteus (MTCC 106), Pseudomonas fluorescens (MTCC 2421), Bacillus licheniformis (MTCC 1251), Rhizopus oryzae (25923), Aspergillus niger (10535), Trichoderma harzianum (MTCC 5179) were analyzed for anti-microbial sensitivity of both the test samples (TCE and TCHG) in comparison to the antibiotics-streptomycin or amphotericin B (Positive control) [58] [59] [60]. On the soft agar plates, sterile well of $9 \mathrm{~mm}$ each was punched and infused with $200 \mu \mathrm{l}$ of the test samples (Aqueous Theobroma cacao extract (TCE), Theobroma cacao Hydrogel (TCHG), gel without extract (HG) and distilled water (DW)). Streptomycin or amphotericin B was selected as a positive control for bacterial and fungal plates $(200 \mu \mathrm{l}) \mathrm{re}$ spectively [61]. The plates were incubated at $37^{\circ} \mathrm{C}$ for $24-48 \mathrm{~h}$. Thereafter, antimicrobial activity was determined by measuring the diameter of zones of inhibition in $\mathrm{mm}[62]$. The means and standard deviation $( \pm \mathrm{SD})$ of the diameter of zones of growth inhibitions for the treatments are shown in results [63].

\section{Results}

\subsection{Phytocompounds Estimation}

The presence of the total phenolic content in $T$. cacao extract was determined by the Folin-Ciocalteu method, the total phenolic content in the extract was found to be $97.58 \pm 1.38 \mathrm{mg} / \mathrm{ml}$. Similarly, the presence of total flavonoids content in TCE was estimated by $\mathrm{AlCl}_{3}$ method and was found to be $68.02 \pm 0.59 \mathrm{mg} / \mathrm{ml}$, after plotting the standard graph with gallic acid.

\subsection{Fabrication and Optimization of T. Cacao Hydrogel}

The T. cacao extract loaded hydrogel (TCHG) was fabricated by using Carbopol-940 along with the hydro-dispersion of cocoa extract and glycerin as shown in Table 1 (Fabrication and optimization of hydrogel using Carbopol 940 at various concentrations). The drug and polymer ratio were optimized at different concentrations in variable batches (F1, F2, F3, and F4) followed by-physical parameters like $\mathrm{pH}$, viscosity, appearance, homogeneity and dug release content analysis.

Table 1. Fabrication and optimization of hydrogel using Carbopol 940 at various concentrations.

\begin{tabular}{ccccc}
\hline Name of ingredient & F1 & F2 & F3 & F4 \\
\hline Carbopol 940 & $0.50 \%$ & $1 \%$ & $1.50 \%$ & $2 \%$ \\
Glycerin & $30 \mathrm{ml}$ & $30 \mathrm{ml}$ & $30 \mathrm{ml}$ & $30 \mathrm{ml}$ \\
Cocoa extract (TCE) & $1 \%$ & $2 \%$ & $3 \%$ & $4 \%$ \\
\hline
\end{tabular}


The hydrogel inspected for its $\mathrm{pH}$ had all values ranging between $6.4 \pm 0.26$ $6.84 \pm 0.49$, considered safe as per the GRAS (Generally regarded as safe) limits to avoid skin irritation after application. The viscosity of hydrogel formulations ranged from $29.406 \pm 1.08$ cps to $51.814 \pm 1.5 \mathrm{cps}$ and Formulation batch (F4) showed the maximum viscosity as compared to the other formulations. On the contrary, F2 batch formulation exhibited appropriate and desired viscosity of the hydrogel formulated (TCHG) as discussed by Murthy et al., 2012 (Table 2) [41] [42]. Also, it was being observed that all the prepared and optimized formulations (F1 - F4) were homogenous in nature and there was no sign of phase separation, precipitation or agglomeration observed. Thereafter, the results obtained after spreadability testing presented that formulation F4 had minimum (11.94 \pm $0.84 \mathrm{~g} \cdot \mathrm{cm} / \mathrm{s})$ and F2 formulation has maximum $(27.49 \pm 0.30 \mathrm{~g} \cdot \mathrm{cm} / \mathrm{s})$ spreading extension in accordance to their respective viscosities, as discussed earlier (refer to Table 2). The prepared and optimized all the hydrogel formulations were stored at room temperature for further use.

Table 2. Rheological parameters.

\begin{tabular}{ccccc}
\hline Formulation code & F1 & F2 & F3 & F4 \\
\hline $\mathrm{pH}$ & $6.4 \pm 0.26$ & $6.68 \pm 0.54$ & $6.8 \pm 1.26$ & $6.84 \pm 0.49$ \\
Viscosity (cps) & $29.406 \pm 1.08$ & $35.965 \pm 0.56$ & $42.510 \pm 1.3$ & $51.814 \pm 1.5$ \\
$\begin{array}{c}\text { Spreadability } \\
(\mathrm{g} \cdot \mathrm{cm} / \mathrm{s})\end{array}$ & $23.10 \pm 0.07$ & $27.49 \pm 0.30$ & $15.78 \pm 0.67$ & $11.94 \pm 0.84$ \\
\hline
\end{tabular}

\subsection{In-Vitro Drug Release Kinetics}

The in-vitro drug release kinetics of all the batches of TCHG were further assessed for cumulative amount of phenolic content released in 12 hours. It was found that the in-vitro drug release was best explained by Hixon's equation, as the plots showed the highest linearity $\left(R^{2}=0.9931\right)$, followed by Higuchi's equation $\left(R^{2}=0.9912\right)$. As it is clear from Table 3 below that the maximum release of drug was obtained at $12^{\text {th }}$ hour in F2 formulation. The linear profile (approx.) as shown in Figure 1 was seen in all the formulations. The expected characteristics of hydro particles of sustained release were verified. The compound release from the hydrogel were clearly observed to attain $90.94 \%$ in 12 hours and on the order of release rate obtained for all the formulations (Table 4) we can rank them in the following descending order F2 $>$ F $3>$ F4 $>$ F1.

Table 3 illustrates the profile of in-vitro release of T. cacao extract from various formulations of TCHG hydrogel. It is clearly observed that over $90 \%$ of $T$. Cacao was released from F2 formulation within $12 \mathrm{~h}$, whereas F1, F3 and F4 released less than $80 \%$ of drug during this period. These three formulations (F1, F3 and F4) had a consistent release rate over $8 \mathrm{~h}$, after which the release rate gradually decreased and became constant with only a slight fluctuation. Moreover, F2 had the highest release rate, while F1 exhibited the lowest rate, indicating that the addition of polymer reduces the rate of release of the drug. This was primar- 
ily because of the presence of carbopol-940 which raised the viscosity in the system and the high viscosity served to retard the diffusion of the drug. Additionally, the dialysis membrane method adopted in the present study allowed permeation of water molecules across the dialysis membrane. Considerable structural changes thus occurred, including alteration of shape and size distribution of the pores, due to progressive swelling of hydrophilic composite hydrogels, resulting in an increase in the tortuosity during the diffusional release of the drug [64].

Table 3. Drug release kinetics of hydrogel formulations.

\begin{tabular}{|c|c|c|c|c|c|c|}
\hline \multicolumn{2}{|c|}{$\begin{array}{l}\text { Time } \\
\text { (hours) }\end{array}$} & $\begin{array}{c}\text { F1 } \\
\text { (\% drug release) }\end{array}$ & \multicolumn{2}{|c|}{$\begin{array}{c}\mathrm{F} 2 \\
\text { (\% drug release) }\end{array}$} & $\begin{array}{c}\text { F3 } \\
\text { (\% drug release) }\end{array}$ & $\begin{array}{c}\mathrm{F} 4 \\
\text { (\% drug release) }\end{array}$ \\
\hline 0 & & 0.05 & \multicolumn{2}{|l|}{0.13} & 0.11 & 0.09 \\
\hline 1 & & 16.16 & \multicolumn{2}{|c|}{22.97} & 21.34 & 20.55 \\
\hline 2 & & 32.44 & \multicolumn{2}{|c|}{38.92} & 36.4 & 33.55 \\
\hline 3 & & 47.94 & \multicolumn{2}{|c|}{52.23} & 51.22 & 47.49 \\
\hline 4 & & 53.61 & \multicolumn{2}{|c|}{60.32} & 58.15 & 55.61 \\
\hline 5 & & 59.63 & \multicolumn{2}{|c|}{65.49} & 64.6 & 63.79 \\
\hline 6 & & 64.59 & \multicolumn{2}{|c|}{75.62} & 73.55 & 72.29 \\
\hline 7 & & 73.41 & \multicolumn{2}{|c|}{81.88} & 79.35 & 78.17 \\
\hline 8 & & 78.11 & \multicolumn{2}{|c|}{88.29} & 80.36 & 79.20 \\
\hline 9 & & 78.26 & \multicolumn{2}{|c|}{89.03} & 80.44 & 78.79 \\
\hline 10 & & 78.35 & \multicolumn{2}{|c|}{89.96} & 79.63 & 78.57 \\
\hline 11 & & 78.44 & \multicolumn{2}{|c|}{90.57} & 78.95 & 78.49 \\
\hline 12 & & 77.26 & \multicolumn{2}{|c|}{90.94} & 78.93 & 78.21 \\
\hline 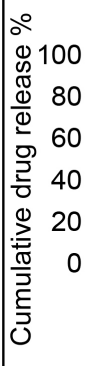 & & $\begin{array}{l}45678 \\
\text { Time in hours }\end{array}$ & 111213 & 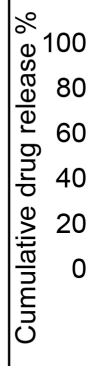 & $\begin{array}{r}123456 \\
\\
\quad \text { Time in }\end{array}$ & $\begin{array}{l} \\
910111213 \\
\text { ours }\end{array}$ \\
\hline 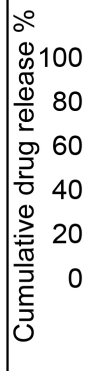 & & $\begin{array}{l}45678 \\
\text { Time in hou }\end{array}$ & 111213 & 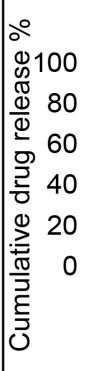 & $\begin{array}{r}123456 \\
\\
\\
\quad \text { Time in }\end{array}$ & 8910111213 \\
\hline
\end{tabular}

Figure 1. Drug release of F1, F2, F3, F4 formulations. 
Table 4. Drug release model.

\begin{tabular}{cccccc}
\hline Formulation & $\begin{array}{c}\text { Zero } \\
\text { order }\end{array}$ & $\begin{array}{c}\text { First } \\
\text { order }\end{array}$ & Higuchi & Hixson-equation & Korsmeyer-Peppas \\
\hline F2 & 0.985 & 0.913 & 0.909 & 0.985 & 0.781 \\
\hline
\end{tabular}

\subsection{Scanning Electron Microscopy (SEM)}

The SEM analysis of morphology of TCHG (F2) depicted the uneven and apparently flaky surface appearance with average porosity, giving avenue for decent extract loading capacity followed by controlled release characteristics. The balanced viscosity in the TCHG (F2) formulation might have led to an efficient inter micellar continuities in the hydrogel composites resulting in increased storage coefficients and long hydrophilic chain as shown in Figure 2.
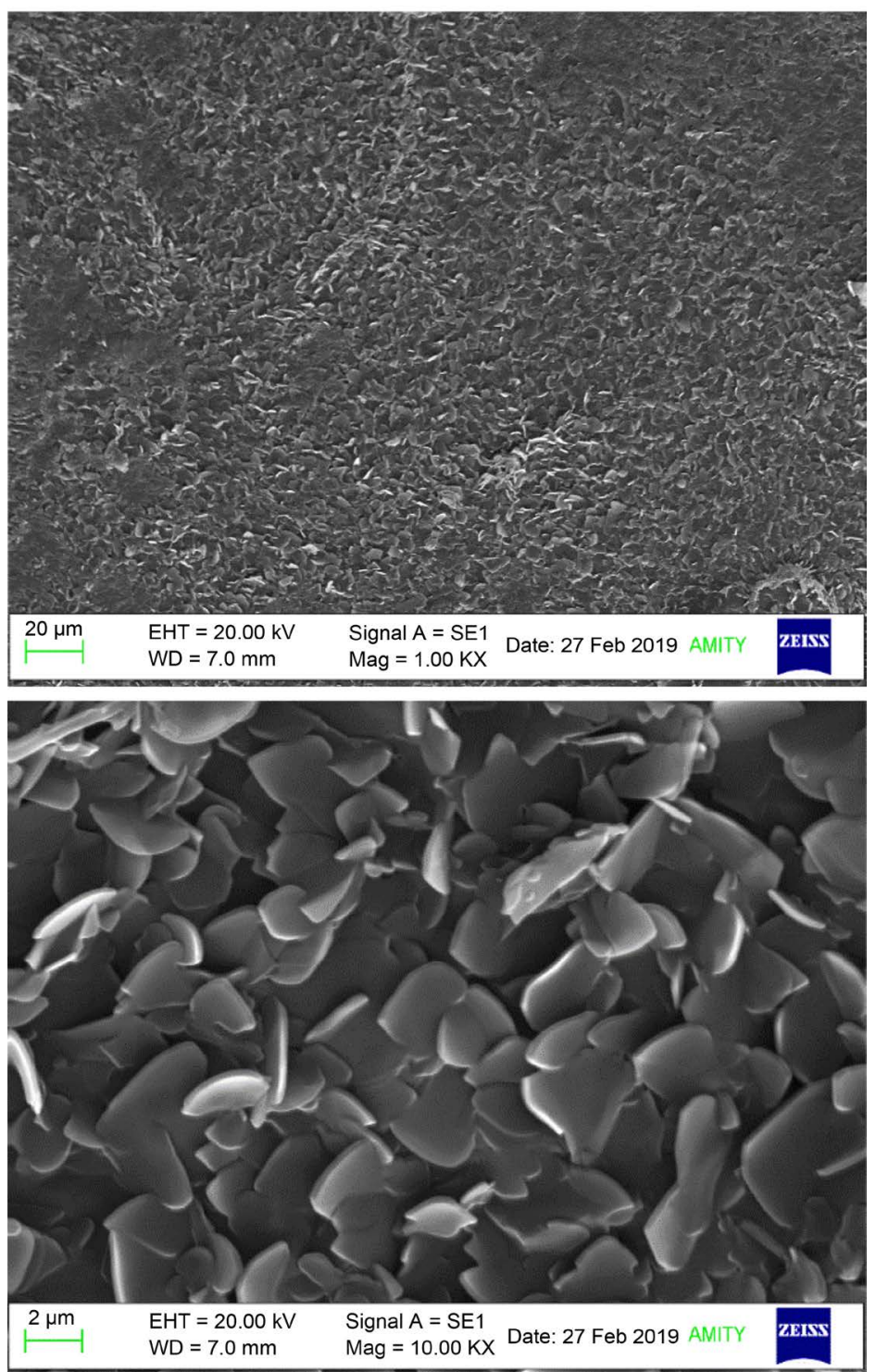

Figure 2. SEM analysis of TCHG at the magnification of $1.00 \mathrm{KX}$ and $10.00 \mathrm{KX}$ respectively. 


\subsection{Antioxidant (AO) and Antiradical Analysis}

The standard graph of Ascorbic acid (AA) at different concentration (10 - 50 $\mu \mathrm{g} / \mathrm{ml}$ ), and was analyzed $517 \mathrm{~nm}$. After plotting the values on the standard graph the $\mathrm{R}^{2}$ value was found out to be 0.996 . Thereafter the same the antioxidant activity was evaluated for cocoa gel as well as the extract.

\subsection{Radical Scavenging Assay (DPPH)}

The antioxidant activity was plotted against various concentration (10 - 50 $\mu \mathrm{g} / \mathrm{ml}$ ) of test samples Theobroma cacao extract (TCE) and cocoa gel (TCHG). The antioxidant activity of gel was found out to be maximum at the concentration of $50 \mu \mathrm{g} / \mathrm{ml}$ which was $92.15 \% \pm 1.42 \%$ whereas; the extract shows the \% antioxidant activity of $40.31 \% \pm 1.13 \%$ at the same concentration as shown in Figure 3. Therefore, it was well reflected from the results that cocoa gel (TCHG) has a maximum antioxidant activity followed by the standard (AA) as shown in Table 5.

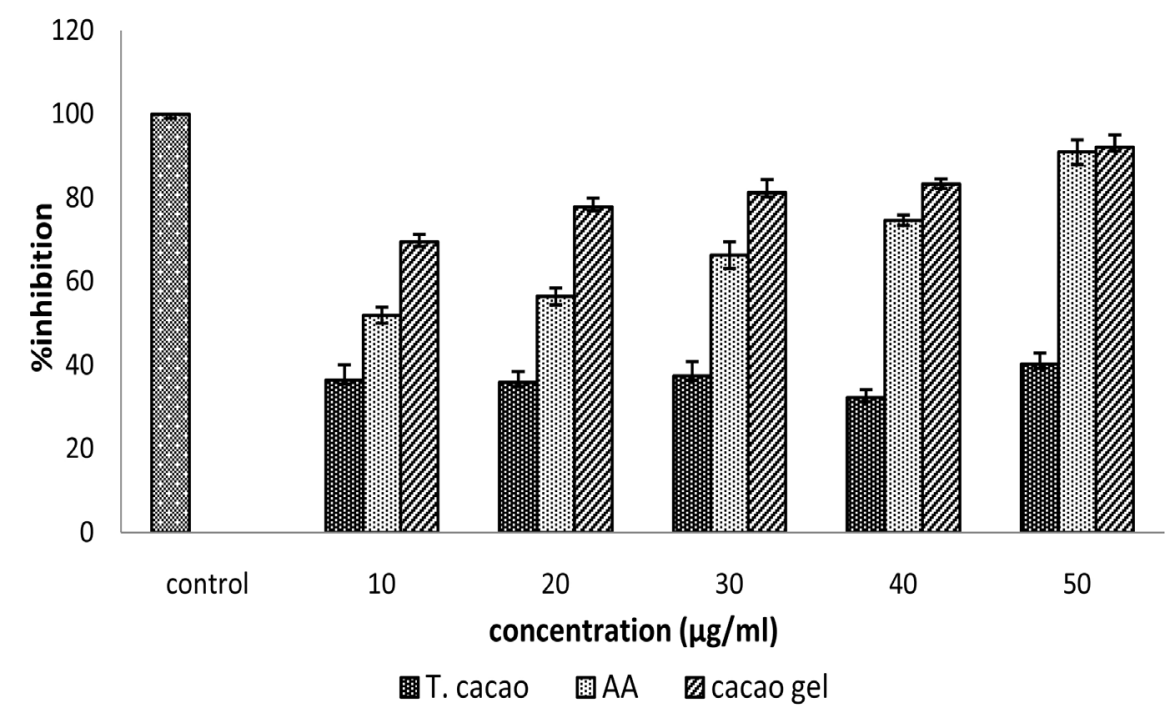

Figure 3. The Graph depicting DPPH Radical scavenging activity (\%) of T. cacao (TCE), cacao gel (TCHG) and standard (AA) at different concentration.

Table 5. Showing the percentage of DPPH radical scavenging activity.

\begin{tabular}{cc}
\hline Test sample & Radical scavenging activity \\
\hline Theobroma cacao & $48.72 \% \pm 1.48 \%$ \\
Ascorbic acid & $76.85 \%$ \\
Cocoa gel & $80.93 \% \pm 1.81 \%$ \\
\hline
\end{tabular}

\subsection{2,2-Azinobis (3-Ethylbenzothiazoline-6-Sulfonic Acid) Radical Assay (ABTS)}

The antioxidant activity was plotted against various concentration (10 - 50 
$\mu \mathrm{g} / \mathrm{ml}$ ) of test samples Theobroma cacao extract (TCE) as well as cocoa gel (TCHG). The antioxidant activity of gel was found out to be maximum at the concentration of $50 \mu \mathrm{g} / \mathrm{ml}$ which was $95.27 \% \pm 1.69 \%$ whereas; the extract shows the $\%$ antioxidant activity of $60.12 \% \pm 1.23 \%$ at the same concentration as shown in Figure 4. Therefore, it was well reflected from the results that cocoa gel (TCHG) has a maximum antioxidant activity followed by extract and the standard AA as shown in Table 6.

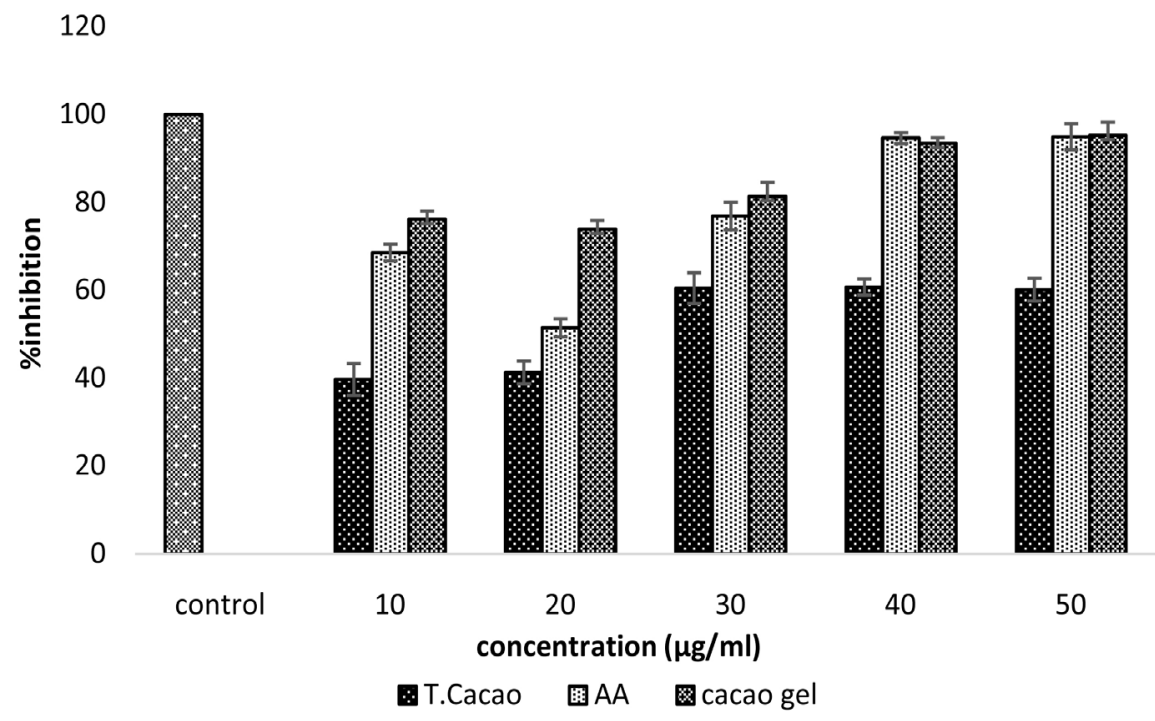

Figure 4. The Graph depicting ABTS scavenging activity (\%) of T. cacao extract (TCE), cacao gel (TCHG) and standard (AA) at different conc.

Table 6. Showing the percentage of ABTS radical scavenging activity.

\begin{tabular}{cc}
\hline Test sample & Radical scavenging activity-ABTS \\
\hline Theobroma cacao & $56.25 \% \pm 1.51 \%$ \\
Cocoa gel & $79.39 \% \pm 1.63 \%$ \\
Ascorbic acid & $74 \%$ \\
\hline
\end{tabular}

\subsection{Hydrogen Peroxide Scavenging Activity $-\mathrm{H}_{2} \mathrm{O}_{2}$ Assay}

The scavenging behavior of the test samples $T$. cacao extract (TCE) as well as cocoa gel (TCHG) was dose-dependent as it increases with the increase in concentration. The antioxidant activity was plotted against various concentration $(10-50 \mu \mathrm{g} / \mathrm{ml})$ of test samples Theobroma cacao extract (TCE) as well as cocoa gel (TCHG). The antioxidant activity of gel was found out to be maximum at the concentration of $30 \mu \mathrm{g} / \mathrm{ml}$ which was $98.12 \% \pm 0.42 \%$ whereas; the extract shows the $\%$ antioxidant activity of $57.13 \% \pm 1.13 \%$ at the same concentration as shown in Figure 5. Therefore, it was well reflected from the results that cocoa gel (TCHG) has a maximum antioxidant activity followed by extract (TCE) and the standard (AA) as shown in Table 7. 


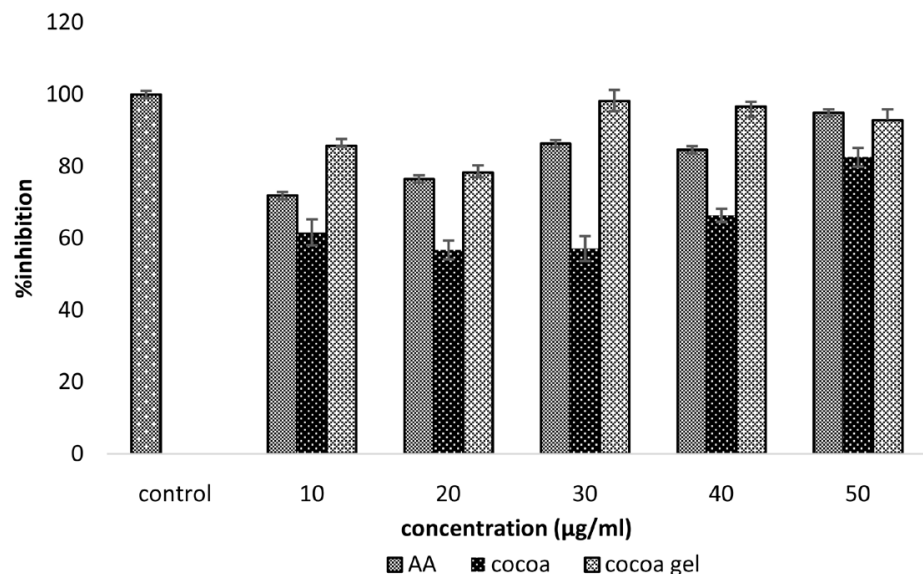

Figure 5. The Graph Depicting $\mathrm{H}_{2} \mathrm{O}_{2}$ scavenging activity (\%) of cocoa extract (TCE), cocoa gel (TCHG) and standard (AA) at different concentration.

Table 7. Showing percentage of $\mathrm{H}_{2} \mathrm{O}_{2}$ scavenging activity.

\begin{tabular}{cc}
\hline Test sample & scavenging activity $-\mathrm{H}_{2} \mathrm{O}_{2}$ assay \\
\hline Theobroma cacao & $72.90 \% \pm 1.51 \%$ \\
Cacao gel & $91.23 \% \pm 0.55 \%$ \\
Ascorbic acid & $78.85 \%$ \\
\hline
\end{tabular}

\subsection{Nitric Oxide Scavenging Activity—NO Assay}

The antioxidant activity was plotted against various concentration (10 - 50 $\mu \mathrm{g} / \mathrm{ml}$ ) of test samples Theobroma cacao extract (TCE) as well as cocoa gel (TCHG). The antioxidant activity of gel was found out to be maximum at the concentration of $50 \mu \mathrm{g} / \mathrm{ml}$ which was $92.54 \% \pm 0.69 \%$ whereas; the extract shows the $\%$ antioxidant activity of $61.5 \% \pm 1.43 \%$ at the same concentration as shown in Figure 6. Therefore, it was well reflected from the results that cocoa gel (TCHG) has a maximum antioxidant activity followed by extract (TCE) and the standard (AA) as shown in Table 8.

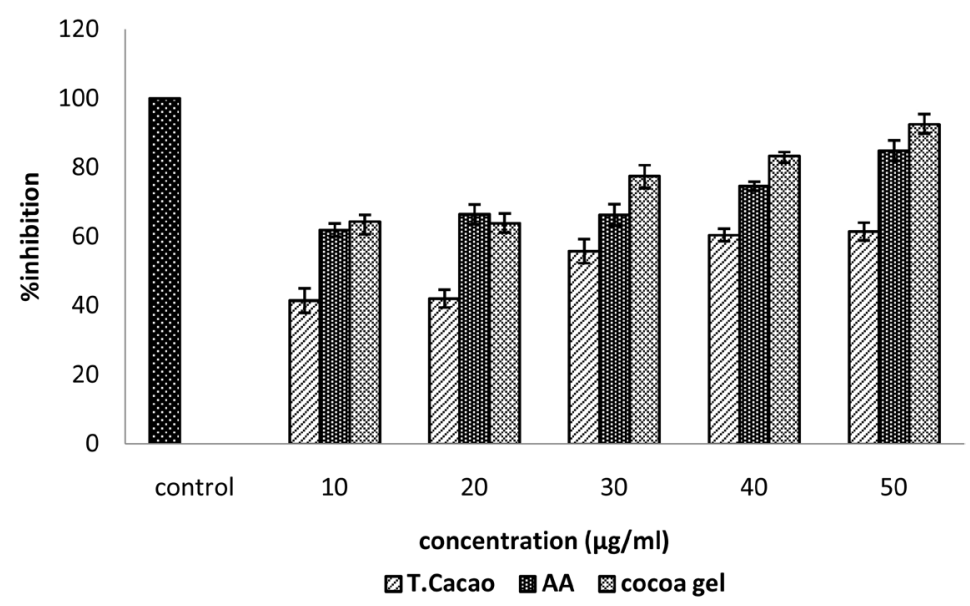

Figure 6. The Graph depicting NO scavenging activity (\%) of T. cacao extract (TCE), cocoa gel (TCHG) and standard (AA) at different conc. 
Table 8. Showing percentage of NO scavenging activity.

\begin{tabular}{cc}
\hline Test sample & scavenging activity-NO assay \\
\hline Theobroma cacao & $58.90 \% \pm 1.51 \%$ \\
Cocoa gel & $95.17 \% \pm 1.14 \%$ \\
Ascorbic acid & $85.16 \%$ \\
\hline
\end{tabular}

\subsection{Antimicrobial Activity}

When the samples were loaded in the agar plates, there occurs the diffusion of the sample into the well which leads to the inhibition of growth of microbes in and around the wells loaded with samples. These inhibitions are clearly seen in the plates after incubation of 24 hours to 72 hours for anti-bacterial and anti-fungal activity. These zones are marked and then measured in $\mathrm{mm}$ which determines the inhibition of the microbes by the test samples as shown in Figure 7. Out of the 3 bacterial strains used, maximum inhibition zones were found in the species of Bacillus licheniformis. These zones were measured as shown in Table 9 and were further analyzed for MIC calculation as shown in Table 10. It was seen that the cocoa extract showed maximum activity against Pseudomonas fluorescens, Bacillus licheniformis, A. niger, Trichoderma as the maximum zones of inhibition were found in it but shows activity against rest of the strains too. Out of both bacterial and fungal strains cocoa showed distinct zones and was further reported for estimation of Minimum Inhibitory Concentration (MIC). MIC is calculated by the diameter of the zones of inhibition. The diameter of the inhibition zones is directly proportional to the concentration of the antibiotics.

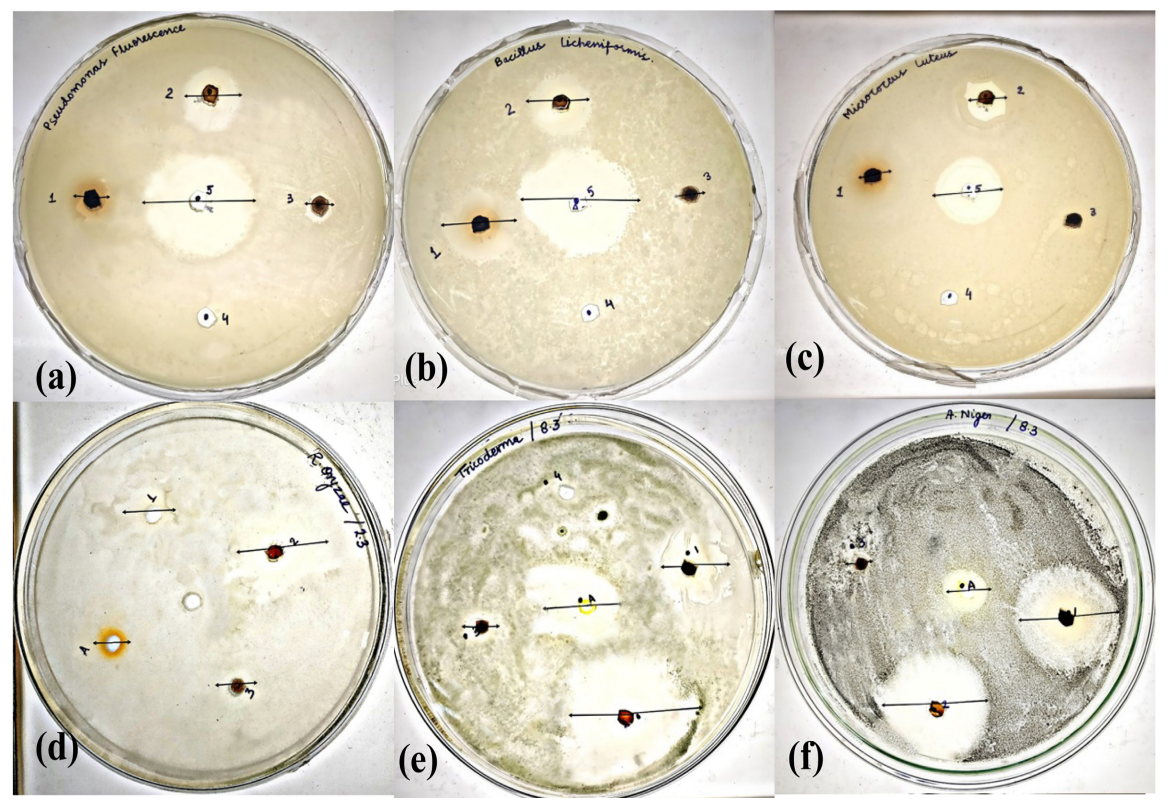

Figure 7. Zones of inhibition in microbial strains. (a) Pseudomonas fluorescens; (b) Bacillus licheniformis; (c) Micrococcus luteus; (d) Rhizopus oryzae; (e) Trichoderma; (f) Aspergillus niger. Where each well represents following test samples-1.TCE; 2. TCHG; 3. gel without extract HG; 4. distilled water DW; 5. Antibiotic. 
Table 9. Zones of inhibition of different cocoa samples TCE, TCHG and HG on different microbial strains.

\begin{tabular}{|c|c|c|c|c|c|c|}
\hline Test sample & $\begin{array}{c}\text { Pseudomonas } \\
\text { fluorescens }\end{array}$ & $\begin{array}{c}\text { Bacillus } \\
\text { licheniformis }\end{array}$ & $\begin{array}{c}\text { Micrococcus } \\
\text { luteus }\end{array}$ & $\begin{array}{c}\text { Rhizopus } \\
\text { oryzae }\end{array}$ & $\begin{array}{c}\text { Trichoderma } \\
\text { harzianum }\end{array}$ & $\begin{array}{l}\text { Aspergillus } \\
\text { niger }\end{array}$ \\
\hline TCE & $25 \pm 1.06 \mathrm{~mm}$ & $25 \pm 1.54 \mathrm{~mm}$ & $15 \pm 1.16 \mathrm{~mm}$ & $14 \pm 1.33 \mathrm{~mm}$ & $45 \pm 1.21 \mathrm{~mm}$ & $45 \pm 1.14 \mathrm{~mm}$ \\
\hline TCHG & $25 \pm 1.39 \mathrm{~mm}$ & $30 \pm 1.16 \mathrm{~mm}$ & $23 \pm 0.96 \mathrm{~mm}$ & $25 \pm 1.73 \mathrm{~mm}$ & $60 \pm 0.09 \mathrm{~mm}$ & $45 \pm 1.7 \mathrm{~mm}$ \\
\hline $\begin{array}{l}\text { Gel without } \\
\text { extract HG }\end{array}$ & $12 \pm 1.32 \mathrm{~mm}$ & $3 \pm 1.81 \mathrm{~mm}$ & $2 \pm 1.43 \mathrm{~mm}$ & $8 \pm 1.29 \mathrm{~mm}$ & $12 \pm 1.75 \mathrm{~mm}$ & $0 \pm 1.31 \mathrm{~mm}$ \\
\hline $\begin{array}{l}\text { Positive control } \\
\text { (antibiotic) }\end{array}$ & $40 \pm 1.6 \mathrm{~mm}$ & $50 \pm 1.4 \mathrm{~mm}$ & $35 \pm 1.6 \mathrm{~mm}$ & $10 \pm 1.55 \mathrm{~mm}$ & $40 \pm 1.59 \mathrm{~mm}$ & $20 \pm 1.6 \mathrm{~mm}$ \\
\hline
\end{tabular}

\section{Minimum Inhibitory Concentration:}

$$
X=(a-b) / 2 \text {; }
$$

where $a=$ diameter of the inhibition zones, $b=$ diameter of the well.

Then plotting the relation between $\mathrm{X}^{2}$ and $\log$ (concentration) and from the curve the MIC is calculated. The antilog of the value of the intercept falling on the $\mathrm{X}$-axis determines the MIC of the sample [65].

Table 10. Minimum inhibitory concentration of test samples on different microbial strains.

\begin{tabular}{cccc}
\hline organism & $\mathrm{d}$ & $10^{\chi}$ & $\mathrm{MIC}(\mu \mathrm{g} / \mathrm{ml})$ \\
\hline Pseudomonas fluorescens & 1.39 & $10^{1.397}$ & $24.94 \pm 1.02$ \\
Bacillus licheniformis & 1.4 & $10^{1.4}$ & $25.11 \pm 1.47$ \\
Micrococcus luteus & 1.43 & $10^{1.43}$ & $10^{1.48}$ \\
Rhizopus oryzae & 1.48 & $10^{1.36}$ & $30.19 \pm 0.39$ \\
Trichoderma & 1.36 & $10^{1.33}$ & $22.90 \pm 0.69$ \\
Aspergillus niger & 1.33 & & $21.37 \pm 0.58$ \\
\hline
\end{tabular}

\section{Discussion}

In the quantitative analysis of the cocoa extract which is done to confirm the presence of certain phyto-constituents as well quantify the amount of these phyto-chemicals in the plant. The quantification of metabolites helps determine the impact of presence and amount of heavy metal present in the sample on the over-all well-being of the plants [66]. Moreover, since these metabolites are responsible for imparting health benefits to the host upon consumption, thus it is essential to understand the extent of impact of these metals on plants to correlate their effect on humans [67].

This correlation is done by assessment and quantification of phytoconstituents in the plants which are the major toxicants being discussed. The rest of the analysis includes the estimation of total phenolics and flavonoid content [68]. It was observed and estimated by R. Gunawan et al., that there was high content of phenolics and flavonoids present in the sample of cocoa which shows many the- 
rapeutic effects and has much more value in the same way the results obtained in this study was approximately near to the values as described above [69] [70]. Hence, the study of Theobroma cacao is validated to the best of knowledge.

Hydrogel formulation containing cocoa hydrogel was successfully prepared and showed effective as well as better carrier for the transdermal drug delivery. The formulated hydrogel was optimized for $\mathrm{pH}$, viscosity, drug release, extrudability, homogeneity [71]. As per Ashwini Jaybhave et al., administration of this through dermal route bypasses the disadvantages of oral route and maintain the consistent plasma levels for the therapy of single dose [72]. Therefore, as proved by Pritam Nikam et al., the results showed that the gel had the ability to retain the original properties for the duration of 6 months which proved the hydrogel formulation to be better and cost-effective in comparison to oral doses [73] [74]. In the same way, the formulations reported in this study reflected the same effectiveness when compared to the work done during this thesis, hence the optimization of the hydrogel and the drug release kinetics were found nearly similar which proves the authenticity of the work [75] [76] [77].

There are various elements involved in the "antioxidant paradox," which has recently been analyzed by Halliwell et al. For example, the use of high doses of antioxidants may actually be detrimental, with lower doses being more beneficial, as is the case with catechin and epicatechin (Halliwell, 2009) [78] [79]. Moreover, the potential value of antioxidants is often low due to their low levels in cells and tissue, thus limiting their possible use as therapeutic drugs [80]. For example, in the therapeutic strategies to prevent progressive neuronal loss based on antioxidant activity, the antioxidant must be able to cross the blood brain barrier and be present at the respective brain region for neuroprotection or the transdermal layer for skin cancers (Aruoma, 2003) [81]. That being said, food, nutraceuticals, and complementary medicines facilitate the administration or ingestion of high quantities of antioxidant compounds, which can produce high or moderate levels of antioxidant agents in the blood and tissue [82] [83]. This protects the natural antioxidants from destruction and consequently reduces cell and tissue damage. To date, numerous studies on the antioxidant activity of plant extracts have been published [84]. Of these, Lee, Kim, Lee, and Lee et al. (2017) compared the antioxidant effects of cocoa extract against cocoa gel extract [85] [86]. These authors observed high activity for the cocoa extract and gel in both ABTS and DPPH tests as well as in $\mathrm{NO}, \mathrm{H}_{2} \mathrm{O}_{2}$, most likely due to a high content in phenolics in it. In the same way, the results obtained during this thesis work validated the study done [87] [88].

The use of $T$. cacao as an anti-microbial agent in many traditional medicinal system has indicated that $T$. cacao may be useful for specific infectious diseases [89]. Hence, there is no need to scientifically evaluate the plant so that it can be used as a novel anti-microbial agent [90]. There are various publications which report the anti-microbial property of $T$. cacao comparison of the present findings with previous publications is difficult. Plants are known to vary in their composition with changes in their habitat and climatic conditions [91]. The 
methods used to check anti-microbial activity of various plant extracts and selection of the test organisms vary between publications. Moreover, a comprehensive report on the activity of $T$. cacao on skin infections causing pathogens is not available [92].

Therefore, the present study indicates that $T$. cacao extracts and gel both have a potent anti-microbial activity against various skin pathogens [93] [94] [95]. However, MIC values (Table 10) indicates that it has higher action against fungal strains than that of the bacterial strains [96]. Moreover, gel extract has a more effective action towards the microbial strains as compared to pure extract which was evident from the MIC values [97]. This indicates that the polyphenolic components of $T$. cacao extract, which are responsible for its anti-microbial activity, are more effective as gel than that of the powder [98]. However, the study reported by Chou et al., P. fluorescens has been found to be more sensitive toward the cocoa extract which confirms the result obtained for the gel extract but the same was not found for the powder extract [99].

Cocoa hydrogel is being prepared using $1 \%$ carbopol-940 as a gelling agent, as it shows better drug release as compared to other formulations, i.e. $90.94 \%$ and the formulation follows Hixon-Crowell model of drug release kinetics. Appearance of the gel was found to be homogenous with no grittiness and brown in colour. The $\mathrm{pH}$ was found to be $6.68 \pm 0.54$ and viscosity $35.965 \pm 0.56$.

\section{Conclusions}

T. cacao has been proved to be very effective in managing many disorders and infections which are associated with skin. Phytochemical studies of $T$. cacao have shown the presence of various versatile and important phytoconstituents such as flavonoids, phenols, alkaloids and saponins. Out of which maximum quantity was estimated for phenolics which was $97.58 \% \pm 1.51 \%$.

The hydrogel prepared showed a good release of drug and had increased bioavailability. The ex-vivo studies of cocoa hydrogel performed showed the maximum drug release of cocoa extract after 12 consecutive hours which proves the effectiveness of the hydrogel. Therefore, the hydrogel containing cocoa proved for in-vitro anti-microbial activity and anti-cancer activity.

On evaluating the antioxidant and antiradical properties of cocoa hydrogel by DPPH, ABTS, NO, $\mathrm{H}_{2} \mathrm{O}_{2}$, it showed that cocoa hydrogel has better radical scavenging effect than the standard of ascorbic acid (AA).

Further results affirmed our study for the activity of cocoa gel against some sensitive bacterial and fungal strains. The anti-bacterial study of cocoa was established against $M$. leuteus (MIC $=26.91 \pm 1.89 \mu \mathrm{g} / \mathrm{ml}$ ), B. licheniformis (MIC $=25.11 \pm 1.47 \mu \mathrm{g} / \mathrm{ml}$ ), $P$. fluorescens $(\mathrm{MIC}=24.94 \pm 1.02 \mu \mathrm{g} / \mathrm{ml}$ ) and for fungal strains $R$. oryzae $(\mathrm{MIC}=30.19 \pm 0.39 \mu \mathrm{g} / \mathrm{ml})$, Trichoderma $(22.90 \pm 0.69 \mu \mathrm{g} / \mathrm{ml})$, A. niger $(21.37 \pm 0.58 \mu \mathrm{g} / \mathrm{ml})$. It further reflects that there can be a hope for the development of many novel products or templates from such plants which may serve for the production of synthetically improved medicinal and therapeutic agents for various disorders. 


\section{Acknowledgements}

The authors wish to thank the Department of Biotechnology, Jaypee Institute of Information Technology, Noida sector-62, Uttar Pradesh, India - 201309 for providing all the facilities, digital journal, library and support during this article writing. We are also thankful to the Amity Institute of Biotechnology, Amity University, Noida sector 125, Uttar Pradesh, India - 201313.

\section{Conflicts of Interest}

The authors declare no conflict of interest.

\section{Author Contributions}

Conceptualization, SHRIYA AGARWAL, VANDANA TYAGI and MANISHA SINGH Methodology, SHRIYA AGARWAL and MANISHA SINGH; Software, SHRIYA AGARWAL, VANDANA TYAGI, MUGDHA AGARWAL; Validation, SHRIYA AGARWAL; Formal Analysis, MANISHA SINGH, RACHANA; Investigation, MANISHA SINGH; Resources, SHRIYA AGARWAL, VANDANA TYAGI; Data Curation, SHRIYA AGARWAL, MANISHA SINGH, MUGDHA AGARWAL; Writing-Original Draft Preparation, SHRIYA AGARWAL, MANISHA SINGH; Writing-Review and Editing, SHRIYA AGARWAL and MANISHA SINGH; Visualization, MANISHA SINGH; Supervision, MANISHA SINGH; Project Administration, MANISHA SINGH.

\section{References}

[1] Peláez, P., Bardón, I. and Camasca, P. (2016) Methylxanthine and Catechin Content of Fresh and Fermented Cocoa Beans, Dried Cocoa Beans, and Cocoa Liquor. Scientia Agropecuaria, 7, 355-365. https://doi.org/10.17268/sci.agropecu.2016.04.01

[2] Pujiyanto, P. (2009) Granules Composed of Cocoa Pod Husk Enriched with Minerals and Their Effects on Growth of Coffee and Cocoa Seedlings. Pelita Perkebunan (A Coffee and Cocoa Research Journal), 25, 24-39.

https://doi.org/10.22302/iccri.jur.pelitaperkebunan.v25i3.112

[3] Meidrieswida, A.G. (2018) Effect of Number of Cocoa Production, World Cocoa Price, Exchange Rate, and Cocoa Export Prices on Cocoa Exports in Indonesia. Jurnal Dinamika Ekonomi Pembangunan, 1, 82-89. https://doi.org/10.33005/jdep.v1i2.73

[4] Arunkumar, K. (2017) Root Morphology and Root Characters of Different Cocoa (Theobroma cacao L.) Types at 100 and 50 Percent Field Capacity under Water Deficit Condition. Journal of Phytology, 9, 10-15.

[5] Adeyeye, I. (2016) Proximate, Mineral and Antinutrient Compositions of Natural Cocoa Cake, Cocoa Liquor and Alkalized Cocoa Powders. Journal of Advanced Pharmaceutical Science and Technology, 1, 12-28. https://doi.org/10.14302/issn.2328-0182.japst-15-855

[6] Demirkol, O., Yiğit, G. and Cerit, İ. (2018) Functional Cocoa and Cocoa Products. The Journal of Food, 43, 702-715. https://doi.org/10.15237/gida.GD18045

[7] Ady, P. (2009) Trends in Cocoa Production. Bulletin of the Oxford University Institute of Economics \& Statistics, 11, 389-404.

https://doi.org/10.1111/j.1468-0084.1949.mp11012003.x 
[8] Susilo, W., Zhang, D. and Motilal, L. (2013) Assessing Genetic Diversity Cocoa ( Theobroma cacao L.) Collection Resistant to Cocoa Pod Borer Using Simple Sequence Repeat Markers. Pelita Perkebunan (a Coffee and Cocoa Research Journal), 29, 1-9. https://doi.org/10.22302/iccri.jur.pelitaperkebunan.v29i1.186

[9] Lamuela-Raventós, R.M., Romero-Pérez, A., Andrés-Lacueva, C. and Tornero, A. (2005) Review: Health Effects of Cocoa Flavonoids. Food Science and Technology International, 11, 159-176. https://doi.org/10.1177/1082013205054498

[10] Akram, M. (2011) Flavonoids and Phenolic Acids: Role and Biochemical Activity in Plants and Human. Journal of Medicinal Plants Research, 5, 6697-6703.

[11] Sies, H. and Stahl, W. (2004) Nutritional Protection against Skin Damage from Sunlight. Annual Review of Nutrition, 24, 173-200. https://doi.org/10.1146/annurev.nutr.24.012003.132320

[12] Scapagnini, G., et al. (2014) Cocoa Bioactive Compounds: Significance and Potential for the Maintenance of Skin Health. Nutrients, 6, 3202-3213. https://doi.org/10.3390/nu6083202

[13] Keen, C., Holt, R., Oteiza, P., Fraga, C. and Schmitz, H. (2005) Cocoa Antioxidants and Cardiovascular Health. The American Journal of Clinical Nutrition, 81, 298S-303S. https://doi.org/10.1093/ajcn/81.1.298S

[14] Lee, K., Kundu, J., Kim, S., Chun, K., Lee, H. and Surh, Y. (2006) Cocoa Polyphenols Inhibit Phorbol Ester-Induced Superoxide Anion Formation in Cultured HL-60 Cells and Expression of Cyclooxygenase-2 and Activation of NF- $\kappa \mathrm{B}$ and MAPKs in Mouse Skin in Vivo. The Journal of Nutrition, 136, 1150-1155. https://doi.org/10.1093/jn/136.5.1150

[15] Holt, R., et al. (2002) Procyanidin Dimer B2 [Epicatechin-(4 $\beta-8)$-Epicatechin] in Human Plasma after the Consumption of a Flavanol-Rich Cocoa. The American Journal of Clinical Nutrition, 76, 798-804. https://doi.org/10.1093/ajcn/76.4.798

[16] Gaur, P., Mishra, S. and Aeri, V. (2014) Formulation and Evaluation of Guggul Lipid Hydro Vesicles for Transdermal Delivery of Aceclofenac. The Scientific World Journal, 2014, Article ID: 534210. https://doi.org/10.1155/2014/534210

[17] Inamdar, Y., Rane, B. and Jain, A. (2018) Preparation and Evaluation of Beta Sitosterol Hydrogel: A Carrier Design for Targeted Drug Delivery System. Asian Journal of Pharmaceutical Research and Development, 6, 81-87. https://doi.org/10.22270/ajprd.v6i3.390

[18] Rehman, K. and Zulfakar, M. (2013) Recent Advances in Gel Technologies for Topical and Transdermal Drug Delivery. Drug Development and Industrial Pharmacy, 40, 433-440. https://doi.org/10.3109/03639045.2013.828219

[19] Talele, S., Nikam, P., Ghosh, B., Deore, C., Jaybhave, A. and Jadhav, A. (2017) A Research Article on Hydrogel as Topical Promising Drug Delivery for Diclofenac sodium. Indian Journal of Pharmaceutical Education and Research, 51, s580-s587. https://doi.org/10.5530/ijper.51.4s.86

[20] Langer, R. (2004) Transdermal Drug Delivery: Past Progress, Current Status, and Future Prospects. Advanced Drug Delivery Reviews, 56, 557-558.

https://doi.org/10.1016/j.addr.2003.10.021

[21] Prausnitz, M., Mitragotri, S. and Langer, R. (2004) Current Status and Future Potential of Transdermal Drug Delivery. Nature Reviews Drug Discovery, 3, 115-124. https://doi.org/10.1038/nrd1304

[22] Narasimha Murthy, S. (2012) Transdermal Drug Delivery: Approaches and Significance. Research and Reports in Transdermal Drug Delivery, 1, 1-2.

https://doi.org/10.2147/RRTD.S31738 
[23] Benson, H. (2005) Transdermal Drug Delivery: Penetration Enhancement Techniques. Current Drug Delivery, 2, 23-33. https://doi.org/10.2174/1567201052772915

[24] 1948 International Life Sciences Institute (1948) Lipotropic Activity of Caffeine, Theobromine, and Theophylline. Nutrition Reviews, 6, 145. https://doi.org/10.1111/j.1753-4887.1948.tb02030.x

[25] Monteiro, J.P., Alves, M.G., Oliveira, P.F. and Silva, B.M. (2016) Structure-Bioactivity Relationships of Methylxanthines: Trying to Make Sense of All the Promises and the Drawbacks. Molecules, 21, 974. https://doi.org/10.3390/molecules21080974

[26] Mart Pinilla, E., Astibia, A. and Franco, R. (2015) The Relevance of the Obromine for the Beneficial Effects of Cocoa Consumption. Frontiers in Pharmacology, 6, 30. https://doi.org/10.3389/fphar.2015.00030

[27] Mitchell, E., et al. (2011) Differential Contributions of Theobromine and Caffeine on Mood, Psychomotor Performance and Blood Pressure. Physiology \& Behavior, 104, 816-822. https://doi.org/10.1016/j.physbeh.2011.07.027

[28] Coulibaly, A., et al. (2016) Daily Intake of Aflatoxins from Cocoa (Theobroma cacao) Product in Cote D'ivoire. International Journal of Science and Research, 5, 1517-1522. https://doi.org/10.21275/v5i5.NOV163664

[29] Ludlow, H. (2014) Chocolate Islands: Cocoa, Slavery, and Colonial Africa. African Historical Review, 46, 89-91. https://doi.org/10.1080/17532523.2014.911443

[30] Heinrich, U., Neukam, K., Tronnier, H., Sies, H. and Stahl, W. (2006) Long-Term Ingestion of High Flavanol Cocoa Provides Photoprotection against UV-Induced Erythema and Improves Skin Condition in Women. The Journal of Nutrition, 136, 1565-1569. https://doi.org/10.1093/jn/136.6.1565

[31] Neukam, K., Stahl, W., Tronnier, H., Sies, H. and Heinrich, U. (2006) Consumption of Flavanol-Rich Cocoa Acutely Increases Microcirculation in Human Skin. European Journal of Nutrition, 46, 53-56. https://doi.org/10.1007/s00394-006-0627-6

[32] Ishaq, S. and Jafri, L. (2017) Biomedical Importance of Cocoa (Theobroma cacao): Significance and Potential for the Maintenance of Human Health. Matrix Science Pharma, 1, 1-5. https://doi.org/10.26480/msp.01.2017.01.05

[33] Martin, M., Goya, L. and Ramos, S. (2013) Potential for Preventive Effects of Cocoa and Cocoa Polyphenols in Cancer. Food and Chemical Toxicology, 56, 336-351. https://doi.org/10.1016/j.fct.2013.02.020

[34] Herraiz, T. (2000) Tetrahydro- $\beta$-Carbolines, Potential Neuroactive Alkaloids, in Chocolate and Cocoa. Journal of Agricultural and Food Chemistry, 48, 4900-4904. https://doi.org/10.1021/jf0005081

[35] Orwa, C., et al. (2009) Agroforestree Database: A Tree Species Reference and Selection Guide Version 4.0. World Agroforestry Centre ICRAF, Nairobi.

[36] Laurence, J.D. (2011) Theobroma cacao L. Interagency Taxonomic Information System, Taxonomic Serial No. 505487.

[37] Biaggioni and Robertson, D. (2009) Quantitative Characterization and Radical Scavenging Activity. Basic \& Clinical Pharmacology, 12, 129-149.

[38] Gorelick, D.A., Gardner, E.L. and Xi, Z.-X. (2004) Agents in Antioxidant Activity Analysis of Theobromine. Drugs, 64, 1547-1573. https://doi.org/10.2165/00003495-200464140-00004

[39] Kosman, M.E. and Klaus, R.U. (1968) Estimation of Total Phenolics. Clinical Pharmacology \& Therapeutics, 9, 240-254. https://doi.org/10.1002/cpt196892240

[40] Sordo, L., et al. (2014) Review On Analyzing ABTS. Drug and Alcohol Dependence, 142, 1-13. https://doi.org/10.1016/j.drugalcdep.2014.06.041 
[41] Gerasimov, R.M., et al. (2000) $\gamma$-Aminobutyric Acid Mimetic Drugs Differentially Inhibit the Dopaminergic Response to Cocaine. European Journal of Pharmacology, 395, 129-135. https://doi.org/10.1016/S0014-2999(00)00267-3

[42] Chavez, B., et al. (2009) An Update on Antimicrobial Property and Its Preliminary Phytoconstituents Analysis. Annals of Pharmacotherapy, 43, 1084-1095. https://doi.org/10.1345/aph.1L523

[43] George, A.J. (2005) Central Nervous System Stimulants and Its Quantitative Screening. In Drugs in Sport, 17, 76-114.

[44] Crutchley, N. and Young, S.J. (2012) Theobromine: Basic Pharmacology, Screening Analysis and Antioxidant Analysis. Anesthesia\& Intensive Care Medicine, 13, 64-66. https://doi.org/10.1016/j.mpaic.2011.11.010

[45] Kosman, M.E. and Klaus, R.U. (2008) Estimation of Total Phenolics. Clinical Pharmacology \& Therapeutics, 9, 288-351.

[46] Chunkto, L., et al. (2017) Analyzing Antioxidants and Their Effects. Drug and Alcohol Dependence, 1, 1-30.

[47] Filip, M., Frankowska, M., Gołda, A., Zaniewska, M., Vetulani, J. and Przegaliński, E. (2006) Various GABA-Mimetic Drugs Differently Affect Cocaine-Evoked Hyperlocomotion and Sensitization. European Journal of Pharmacology, 541, 163-170. https://doi.org/10.1016/j.ejphar.2006.05.011

[48] Boutrel, B. and Koob, G.F. (2004) What Keeps Us Awake: The Neuropharmacology of Stimulants and Wakefulness Promoting Medications. Sleep, 27, 1181-1194. https://doi.org/10.1093/sleep/27.6.1181

[49] Kakhia, T.I. (2012) Alkaloids and Alkaloids Plants. Adana University-Industry Joint Research Center.

[50] Katsuro, T. and Tsuchiya, H. (2015) Caffeine Enhancement of the Effect of Anticancer Agents on Human Sarcoma Cells. Japanese Journal of Cancer Research, 80, 83-88. https://doi.org/10.1111/j.1349-7006.1989.tb02249.x

[51] Catarina, R., Rhodes, J.S. and Spencer, J. (2014) The Mechanisms of Action of Flavonoids in the Dermal Layers: Direct versus Indirect Effects. Neurochemistry International, 89, 126-139. https://doi.org/10.1016/j.neuint.2015.08.002

[52] Singh, M., Agarwal, S. and Tyagi, V. (2018) Alkaloids as CNS Stimulants. In: Alkaloids, Intec Open.

[53] Camandola, S., Plick, N. and Mattson, M.P. (2019) Impact of Coffee and Cacao Purine Metabolites on Neuroplasticity and Neurodegenerative Disease and Various Tumors. Neurochemical Research, 44, 214-227.

[54] Ainhoa, O.-A., Franco, R. and Martínez-Pinilla, E. (2015) Health Benefits of Methylxanthines in Skin Diseases. Molecular Nutrition \& Food Research, 61, 160-670. https://doi.org/10.1002/mnfr.201600670

[55] Lee, L.W., Cheong, M.W., Curran, P., Yu, B. and Liu, S.Q. (2015) Coffee Fermentation and Flavor-An Intricate and Delicate Relationship. Food Chemistry, 185, 182-191. https://doi.org/10.1016/j.foodchem.2015.03.124

[56] Amit, M., Fawal, M. and Estes, R. (2015) Performance-Enhancing Substances: Cocoa-A Review of the Literature. Sports Medicine, 45, 517-531. https://doi.org/10.1007/s40279-015-0308-9

[57] Alexander, M.W. and Stockton, G.G. (2015) Methylphenidate Abuse and Psychiatric Side Effects of Cocoa Powder. Primary Care Companion to the Journal of Clinical Psychiatry, 2, 159.

[58] Heal, D.J., Smith, S.L., Gosden, J. and Nutt, D.J. (2013) Theobromine, Past and 
Present-A Pharmacological and Clinical Perspective. Journal of Psychopharmacology, 27, 479-496. https://doi.org/10.1177/0269881113482532

[59] Badisa, R.B., Batton, C.S., Mazzio, E., Grant, S.C. and Goodman, C.B. (2018) Identification of Biochemical and Cytotoxic Markers in Treated A431 Cells. Scientific reports, 8, 2710. https://doi.org/10.1038/s41598-018-21182-7

[60] Jordan, P.S. (1981) Skin Disorders and Its Treatments. American Journal of Health-System Pharmacy, 38, 29-39. https://doi.org/10.1093/ajhp/38.1.29

[61] Max, M.B., et al. (2002) Effects of Cocoagel and Its Cytotoxicity Analysis. New England Journal of Medicine, 326, 1250-1256. https://doi.org/10.1056/NEJM199205073261904

[62] Walter, S., et al. (2014) A Quantitative Model of Theobromine Action on the 5-HT Transporter. British Journal of Pharmacology, 171, 1007-1018. https://doi.org/10.1111/bph.12520

[63] Coughlin, P.A. and Mavor, A.I.D. (2016) Arterial Consequences of Recreational Drug Use. European Journal of Vascular and Endovascular Surgery, 32, 389-396. https://doi.org/10.1016/j.ejvs.2006.03.003

[64] Thompson, W.G., et al. (2009) Functional Bowel Disorders and Functional Abdominal Pain. Gut, 45, II43-II47. https://doi.org/10.1136/gut.45.2008.ii43

[65] Pleuvry, B.J. (2003) Central Nervous System Stimulants: Basic Pharmacology and Relevance to Anaesthesia. Anaesthesia \& Intensive Care Medicine, 10, 344-347. https://doi.org/10.1016/j.mpaic.2009.03.008

[66] Li, M., Wessinger, W.D. and McMillan, D.E. (2015) Effects of Amphetamine-CNS Depressant Combinations and of Other Stimulants in Four-Choice Drug Discriminations. Journal of the Experimental Analysis of Behavior, 84, 77-97. https://doi.org/10.1901/jeab.2005.09-04

[67] Wallace, L.J. (2012) Effects of Theobromine on Subdermal Distribution of Skin Layers. Synapse, 66, 592-607. https://doi.org/10.1002/syn.21546

[68] Da Silva, D.D., et al. (2003) Mixtures of Cocoa and Its Major Compounds Which Inhibit Significant Toxicity to Skin Cells When Combined at Low, Ineffective Concentrations. Study of the Toxicological Interactions between Cocoa Designer Drugs in the Context of Polydrug Abuse, 1001, 143.

[69] Cappelletti, S., Daria, P., Sani, G. and Aromatario, M. (2016) Caffeine: Cognitive and Physical Performance Enhancer or Psychoactive Drug. Current Pharmacology, 13, 71-88. https://doi.org/10.2174/1570159X13666141210215655

[70] Astrid, N., Daval, J.-L. and Debry, G. (2017) Caffeine and the Central Nervous System: Mechanisms of Action, Biochemical, Metabolic and Psychostimulant Effects. Transdermal Research Reviews, 17, 139-170. https://doi.org/10.1016/0165-0173(92)90012-B

[71] Arunabha, R., et al. (2005) Pharmacological Studies on Mechanisms of Skin Cancers-Induced in Humans. Iranian Journal of Pharmacology and Therapeutics, 5, $12-21$.

[72] Yao, C.P., et al. (2001) Fluvoxamine-Theobromine Interaction: Gap between in Vitro and in Vivo Inhibition Constants toward Cytochrome P4501A2. Clinical Pharmacology \& Therapeutics, 70, 415-424.

[73] Baggott, M.J., et al. (2013) Psychopharmacology of Theobromine in Healthy Volunteers. Psychopharmacology, 228, 109-118. https://doi.org/10.1007/s00213-013-3021-0

[74] Becker, A.B., Simons, K.J., Gillespie, C.A. and Simons, F.E. (2015) The Bronchodi- 
lator Effects and Pharmacokinetics of Caffeine in Asthma. The New England Journal of Medicine, 22, 743-746. https://doi.org/10.1056/NEJM198403223101202

[75] Benjamin, B. and Koob, G.F. (2014) What Keeps Us Awake: The Neuropharmacology of Stimulants and Wakefulness Promoting Medications. Sleep, 27, 1181-1194. https://doi.org/10.1093/sleep/27.6.1181

[76] Rovei, V., Chanoine, F. and Benedetti, S.M. (2018) Pharmacokinetics of Theobromine: A Dose-Range Study. British Journal of Clinical Pharmacology, 14, 769-778. https://doi.org/10.1111/j.1365-2125.1982.tb02035.x

[77] White Jr., J.R., et al. (2008) Pharmacokinetic Analysis and Comparison of Cocoa Administered Rapidly or Slowly in Coffee Chilled or Hot versus Chilled Energy Drink in Healthy Young Adults. Clinical Toxicology, 54, 308-312.

[78] Barry, B.W. (2001) Novel Mechanisms and Devices to Enable Successful Transdermal Drug Delivery. European Journal of Pharmaceutical Sciences, 14, 101-114.

[79] Sordo, L., et al. (2004) Transdermal Drug Delivery: A Review. Current Drug Delivery, 142, 1-13.

[80] Murthy, P.S. and Manonmani, H.K. (2009) Physico-Chemical, Antioxidant and Antimicrobial Properties of Indian Monsooned Coffee. European Food Research and Technology, 229, 645-650. https://doi.org/10.1007/s00217-009-1098-9

[81] Karch, S.B. (2007) Addiction and the Medical Complications of Drug Abuse. CRC Press, Boca Raton, FL. https://doi.org/10.1201/9781420054446

[82] Calatayud, M., López-de-Dicastillo, C., López-Carballo, G., Velez, D., Hernández Muñoz, P. and Gravari, R. (2013) Active Films Based on Cocoa Extract with Antioxidant, Antimicrobial and Biological Applications. Food Chemistry, 139, 51-58. https://doi.org/10.1016/j.foodchem.2013.01.097

[83] Zheng, F., Nsor-Atind, J., Mothibi, K., Banora, M. and Lanoka, C. (2012) Quantification of Total Polyphenolic Content and Antimicrobial Activity of Cocoa (Theobroma cacao L.) Bean Shells. Pakistan Journal of Nutrition, 11, 672-677. https://doi.org/10.3923/pjn.2012.672.677

[84] Lateef, A., et al. (2016) Cocoa Pod Husk Extract-Mediated Biosynthesis of Silver Hydro Particles: Its Antimicrobial, Antioxidant and Larvicidal Activities. Journal of Hydro structure in Chemistry, 6, 159-169. https://doi.org/10.1007/s40097-016-0191-4

[85] Todoroki, V., Milinkovic, M., Vidovic, B., Todorovic, Z. and Sobajic, S. (2017) Correlation between Antimicrobial, Antioxidant Activity, and Polyphenols of Alkalized/Non-Alkalized Cocoa Powders. Journal of Food Science, 82, 1020-1027. https://doi.org/10.1111/1750-3841.13672

[86] Bubonja-Sonje, M., Giacometti, J. and Abram, M. (2011) Antioxidant and Antilisterial Activity of Olive Oil, Cocoa and Rosemary Extract Polyphenols. Food Chemistry, 127, 1821-1827. https://doi.org/10.1016/j.foodchem.2011.02.071

[87] Adi-Dako, O., Ofori-Kwakye, K., Frimpong Manso, S., Boakye-Gyasi, M., Sasu, C. and Pobee, M. (2016) Physicochemical and Antimicrobial Properties of Cocoa Pod Husk Pectin Intended as a Versatile Pharmaceutical Excipient and Nutraceutical. Journal of Pharmaceutics, 2016, Article ID: 7608693. https://doi.org/10.1155/2016/7608693

[88] Huang, Y., et al. (2009) Effects of Luteolin and Quercetin, Inhibitors of Tyrosine Kinase, on Cell Growth and Metastasis-Associated Properties in A431 Cells Overexpressing Epidermal Growth Factor Receptor. British Journal of Pharmacology, 128, 999-1010. https://doi.org/10.1038/sj.bjp.0702879

[89] Spencer, J., Chaudry, F., Pannala, A., Srai, S., Debnam, E. and Rice-Evans, C. (2000) 
Decomposition of Cocoa Procyanidins in the Gastric Milieu. Biochemical and Biophysical Research Communications, 272, 236-241. https://doi.org/10.1006/bbrc.2000.2749

[90] Sagiri, S., Sethy, J., Pal, K., Banerjee, I., Pramanik, K. and Maiti, T. (2012) Encapsulation of Vegetable Organogels for Controlled Delivery Applications. Designed Monomers and Polymers, 16, 366-376. https://doi.org/10.1080/15685551.2012.747154

[91] Langer, R. (1980) Invited Review Polymeric Delivery Systems for Controlled Drug Release. Chemical Engineering Communications, 6, 1-48. https://doi.org/10.1080/00986448008912519

[92] McKinnon, P., Paladino, J. and Schentag, J. (2008) Evaluation of Area under the Inhibitory Curve (AUIC) and Time above the Minimum Inhibitory Concentration (T $>$ MIC) as Predictors of Outcome for Cefepime and Ceftazidime in Serious Bacterial Infections. International Journal of Antimicrobial Agents, 31, 345-351. https://doi.org/10.1016/j.ijantimicag.2007.12.009

[93] Al-Ahmad, A., Daschner, F. and Kümmerer, K. (1999) Biodegradability of Cefotiam, Ciprofloxacin, Meropenem, Penicillin G, and Sulfamethoxazole and Inhibition of Waste Water Bacteria. Archives of Environmental Contamination and Toxicology, 37, 158-163. https://doi.org/10.1007/s002449900501

[94] Lu, P., Lai, C. and Chan, W. (2008) Caffeine Induces Cell Death via Activation of Apoptotic Signal and Inactivation of Survival Signal in Human Osteoblasts. International Journal of Molecular Sciences, 9, 698-718. https://doi.org/10.3390/ijms9050698

[95] Abdul Karim, A., et al. (2014) Phenolic Composition, Antioxidant, Anti-Wrinkles and Tyrosinase Inhibitory Activities of Cocoa Pod Extract. BMC Complementary and Alternative Medicine, 14, 381. https://doi.org/10.1186/1472-6882-14-381

[96] Fraga, C., Hammerstone, J., Lazarus, S., Schmitz, H. and Keen, C. (2001) More Antioxidants in Cocoa. The Journal of Nutrition, 131, 835-835. https://doi.org/10.1093/jn/131.3.835

[97] Sabuhoro, J. (1997) The Market Efficiency Hypothesis: The Case of Coffee and Cocoa Futures. Agricultural Economics, 16, 171-184.

[98] Rolfo, J. (1980) Optimal Hedging under Price and Quantity Uncertainty: The Case of a Cocoa Producer. Journal of Political Economy, 88, 100-116. https://doi.org/10.1086/260849

[99] Jumah, A. (2001) The Effects of Dollar/Sterling Exchange Rate Volatility on Futures Markets for Coffee and Cocoa. European Review of Agriculture Economics, 28, 307-328. https://doi.org/10.1093/erae/28.3.307 